Шимановська-Діаніч Л.М., Гунченко М.В., монографія. - Полтава: РВВ ПУСКУ, 2008. - 161 с.

\section{REFERENCES}

1. Zakon Ukrainy (2010). "Pro zatverdzhennia Zahalnoderzhavnoi prohramy rozvytku mineralnosyrovynnoi bazy Ukrainy na period do 2030 roku" [On Approval of the National Program for the Development of the Mineral Resources of Ukraine until 2030]. [Electronic resource]. Available at: http: // zakon3.rada.gov.ua/laws/show/3268-17.[in Ukrainian].

2. Kobiuk, Yu.M. (2015). Tekhnolohii sytuatyvnoho modeliuvannia u profesiinii pidhotovtsi maibutnikh uchyteliv [Situational modeling technologies in the training of future teachers]. Pedagogical Sciences: Theory, History, Innovative Technologies: Scientific Journal. Sumy: SumMPU. A. S. Makarenko, no. 3 (47), pp. 359 - 364. [in Ukrainian].

3. Kuzko, M. (2017). Future geologists' professional training as a pedagogical problem. Pedagogical sciences: theory, history, innovative technologies. Sumy: SumMPU. A. S. Makarenko, no. 7 (71), pp. 79 -90.[in Ukrainian].
4. Madzigon, V. \& Vachevsky, M. (2012). Promyslovyi marketynh $v$ heolohii, burinnia sverdlovyn $i$ dobuvannia nafty $i$ hazu zi sverdlovyny [Industrial Marketing in Geology, Well Drilling and Extraction of Oil and Gas from a Well]. Youth and Market, no. 2 (85), pp. 6 - 13. [in Ukrainian].

5. Moskalenko, O. A., Moskalenko, Yu. D. \& Kovalenko, O. V. (2012). Sytuatsiini zadachi yak produktyvna osnova suchasnoi systemy fakhovoho stanovlennia maibutnoho vchytelia matematyky [Situational problems as a productive basis of the modern system of professional formation of the future teacher of mathematics]. Pedagogical Science: Theory, History, Innovative Technologies. Sumy: Sum MPU.A. S. Makarenko, no. 2 (56), pp. 347-356. [in Ukrainian].

6. Yurko, I.V. (2008). Vykorystannia treninhovykh tekhnolohii navchannia u pidhotovtsi fakhivtsiv dlia pidpryiemnytskoi ta upravlinskoi diialnosti [Use of training technology training in the training of specialists for entrepreneurial and managerial activities]. Poltava: RVV START, $161 \mathrm{p}$. [in Ukrainian].

Стаття надійшла до редакції 29.01.2018

УДК 378.637

Ольга Гриб, викладач кафедри музичного мистецтва факультету культури і мистецтв Львівського національного університету імені Івана Франка

\title{
ТЕНДЕНЦІЇ РОЗВИТКУ СУЧАСНОЇ МУЗИЧНО-ПЕДАГОГІЧНОЇ ОСВІТИ
}

У статті проаналізовано основні теоретичні аспекти розвитку музично-педагогічної освіти на сучасному етапі. Виокремлено основні стратегічні освітні напрями котрі істотно впливають на підвищення якості освіти. Зроблено акцент на розвиток професійної майстерності вчителя музичного мистецтва. Висвітлено комплекс знань, умінь та навичок якими повинен володіти сучасний педагог-музикант. Складність професійної діяльності педагога-музиканта полягає в тому, що вона вимагає від вчителя знань, умінь та навичок у загально-педагогічній сфері, музично-педагогічній та виконавській.

Ключові слова: музично-педагогічна освіта, педагог-музикант, освітні технологї, музичне мистеитво.

תim. 5.

Olha Hryb, Lecturer of the Musical Art Department Faculty of Culture and Arts Lviv Ivan Franko National University

\section{TRENDS OF DEVELOPMENT OF MODERN MUSIC AND PEDAGOGICAL EDUCATION}

The article analyzes the main theoretical aspects of the development of musical-pedagogical education at the present stage. The main strategic educational directions that significantly influence the quality of education are highlighted. The emphasis is on the development of the professional skill of the teacher of musical art. The complex of knowledge, abilities and skills that a modern music teacher must possess is highlighted. The complexity of the professional activity of a teacher-musician is that it requires a teacher of knowledge, skills and abilities in the general-pedagogical field, musical-pedagogical and performing. In the today's educational environment, the training of future teachers of musical art is aimed at the formation and development of professionals, capable to perform the artistic and creative activities. By actively using the latest technologies of teaching, the student improves the search, creative activity, ascends to a new level of knowledge and activates cognitive activity, independence, interest in their work. The role of musical art in shaping the spirituality of the younger generation is also defined.

Keywords: music-pedagogical education, a teacher of music, the educational technologies, musical art. 
патріотичних почуттів, громадянської позиції. Цінності мистецтва важливі також з огляду на сучасне існування дітей і молоді в полікультурному просторі. Завдяки універсальності художньообразної мови вони передають зрозумілу для різних народів смислову інформацію, дають змогу особистості вступати в невербальний діалог 3 різними культурами минулого і сучасності, розуміти інших і розширювати таким чином свій власний духовний світ, його унікальність і самобутність. Тому, одне 3 головних завдань навчання на музично-педагогічному факультеті сучасних університетів полягає у підготовці майбутнього педагога-музиканта до оптимального розвитку його власного нестандартного педагогічного мислення, здатності чутливо реагувати на духовно-культурні виклики сучасності, зокрема: розуміння вагомості хорового співу та пошуки тих ефективних форм та методів навчання в школі, які є найбільш відповідними сучасним національним критеріям та сприяють утворенню національної ідентичності українців у глобалізованому світовому просторі.

Аналіз останніх досліджень та публікацій. У теорії та практиці музично-педагогічної освіти сучасними науковцями С. Горбенком, О. Лобовою, Л.Масол,О.Михайличенком,О.Олексюк,В.Орловим, Г. Падалкою, Т. Рейзенкінд, О. Ростовськи, М.Л. Хлебніковою, О. Щолоковою. Проведені грунтовні дослідження з проблем професійної підготовки майбутнього вчителя-музиканта.

Мета статті - проаналізувати основні теоретичні аспекти розвитку музичнопедагогічної освіти на сучасному етапі.

Виклад основного матеріалу. Актуальною проблемою сьогодення $€$ систематизація об'єктивних знань про розвиток освітянських процесів, пізнання законів та закономірностей. Але враховуючи певні теоретичні узагальнення та класифікацію музично-педагогічних явищ не можна не надавати особливої уваги викликам та вимогам сучасного суспільства.

Учитель $є$ головною дійовою особою будь-яких перетворень у системі освіти, що вимагає підготовки освічених, мобільних, конструктивних людей, здатних до співпраці, міжкультурної взаємодії, до переорієнтації свідомості на гуманістичні цінності, що є характерними для творчої (інноваційної) педагогічної діяльності.

Науковці виокремлюють специфічні риси організації навчально-виховного процесу та накреслюють коло першочергових питань, від вирішення яких залежить здатність майбутнього спеціаліста до виконання професійних завдань. Особлива увага приділяється розвитку у студентів конкретних умінь та навичок: диригентських, педагогічних, виконавських, музичного сприйняття тощо.

Осмислення складових елементів національної спадщини дозволяє визначити роль музичного мистецтва у формуванні духовності підростаючого покоління. Як специфічна форма суспільної свідомості, що в концентрованому вигляді відображає цінності минулого й сучасного, музика узагальнює багатовіковий досвід духовноемоційного ставлення до світу, допомагає людині глибоко пізнати себе, свій внутрішній світ, активізувати творчі сили, розкрити внутрішній духовний потенціал. Серед різноманітних засобів формування особистості важливе місце належить музичному мистецтву, одному 3 наймогутніших засобів розкриття індивідуальних креативних здібностей, розширення інтелектуального обрію та формування естетичних смаків зрілої особистості.

Найбільша відповідальність в цьому процесі лягає на музичного керівника дошкільних закладів та вчителя музичного мистецтва загальноосвітньої школи, оскільки саме в дитинстві та юності укладається цілісний особистісний комплекс розумових та емоційних характеристик особистості. Відтак ця професія потребує не тільки глибоких знань, любові до дітей, сформованої системи вмінь і навичок, але й самостійного творчого мислення. Тільки висококваліфікований учитель, який розуміє та любить мистецтво, володіє комплексом знань, умінь і навичок у різноманітних галузях музично-педагогічної діяльності, зможе прилучити сучасних школярів до світу мистецтва.

Завданнями вчителів мистецьких дисциплін стають: надання знання учням про види мистецтва та засоби їх виразності, розвиток художньо-естетичних емоцій, смаків, почуттів, розвиток здатності дітей виражати власне ставлення до мистецтва, здатності до творчої діяльності у мистецькій сфері та самореалізації, вироблення загальної потреб в спілкуванні 3 мистецтвом, володіння учнями системою елементарних мистецьких знань, понять, термінів та розвиток вмінь адекватно сприймати художні твори різних видів мистецтва.

На превеликий жаль, в сучасних умовах технічного прогресу дітей важко залучити до звичної діяльності “вчорашніх” учнів, відірвати від телефонів, ноутбуків, планшетів та інших пасток. Все менше і менше дітей є задіяними у творчих колективах, не вистачає живого спілкування та позитивних емоцій.

Сьогодні педагоги-музиканти та керівники 
дитячих вокально-хорових колективів все більше звертають увагу на ту відповідальність, яку беруть на себе, виховуючи прекрасне в дитячих душах. Все частіше саме педагоги стають наставниками для учасників свого колективу, засіваючи все найкраще у їхні серця за допомогою музики.

Визначена проблема спрямована на удосконалення змісту професійної освіти майбутніх фахівців, котра пов'язана із суттєвими змінами у їх якісній підготовці, яких вимагає сучасність. Можливість удосконалення цієї підготовки може реалізуватись за рахунок класифікації, обгрунтування та впровадження цілісної системи формування професійної майстерності майбутніх учителів, зорієнтованих на оптимальне досягнення поставленої мети. "На стикові XX - XXI століть започаткувалась “культуротворча" освіта 3 уявленнями про гуманістичний тип особистості, яка не лише споживає культурні цінності, але й примножує їх. Центрування “вирощування” творчої особистості, їі саморозвитку в освіті разом 3 появою численних моделей інноваційного навчання знаменує кардинальну зміну типу соціокультурного успадкування, яким забезпечується перевага нового над копіюванням старого" [2, 40].

Адже сьогодні важливого значення набуває проблема розробки науково обгрунтованої стратегії та тактики подальшого розвитку музично-педагогічної освіти як цілісної системи підготовки висококваліфікованих фахівців. У нормативних документах вказано, що необхідно вивести вищу освіту України на рівень розвинутих країн світу через докорінне реформування концептуальних, структурних й організаційних засад навчально-виховного процесу, забезпечивши і1і випереджувальний характер, що дозволить поглибити ефективність вищої освіти, інтегрувати іiї в європейський та світовий простір. Науковці підкреслюють важливість такого підходу до розуміння підготовки студента, у результаті якого він розглядається не тільки як майбутній професіонал, a як глибоко компетентнісний фахівець, скерований на постійне самовдосконалення. Освіта у цьому сенсі виступає як соціальний захист особистості проти деяких негативних інформаційних впливів, котрі націлені на нівелювання значення багатоаспектного становлення майбутнього фахівця.

Отже, методологічною основою підготовки майбутніх вчителів мистецьких дисциплін можна вважати системно-цілісний, категоріальний, особистісний та діяльнісно-творчий підходи.
Феномен майстерність визначений як індивідуальна ознака професіонала в активному діяльнісному процесі. Необхідною складовою майстерності є творчість, креативність мислення як ознака обдарованості особистості. Стрижнем майстерності педагога-музиканта $€$ компетентність на основі базових знань, культура спілкування (комунікативна опосередкованість), авторитет, імідж, репутація як норма соціально-психологічної поведінки особистості.

Зміна пріоритетів вимагає, перш за все, зміни функцій учителя, адже $з$ транслятора знань він перетворюється в організатора та стимулятора самостійної пізнавальної діяльності у навчальновиховному процесі, застосування інноваційних технологій зумовлює необхідність підготовки вчителя до впровадження нових методів $[1,113]$.

Значна увага у підготовці викладачів у зарубіжних країнах приділяється формуванню вміння налагодження взаємодії учасників педагогічного процесу. На думку зарубіжних учених, взаємодія розглядається як засіб організації та активізації самостійної роботи студентів, іiї стимулюючим фактором. Вони також відмічають мотиваційну здатність до неперервної освіти активний пошук можливостей підвищення рівня професійних знань у процесі самостановлення.

М. Фулан у книзі “Сили змін: вимірювання глибини освітніх реформ” зазначав, що життя не “підпорядковується прямолінійній логіці, воно має викривлену логіку, яка змінює природу речей i перетворює іiї на протилежну. Проблеми - не просто незручності з якими потрібно впоратись і відкинути їх. Аналіз кожної проблеми - це майстерня 3 природи організації і двигун для особистого зростання. Це підвищує цінність процесу пошукурішень, подібного до жонглювання складовими значущого рішення" $[5,60]$.

Професор А.В. Козир у своїй монографії “Професійна майстерність учителів музики: теорія і практика формування в системі багаторівневої освіти” виокремлює основні стратегічні освітніми напрями, котрі є найбільш ефективними у багатьох країнах та істотно впливають на підвищення якості освіти, а саме: інтерактивну та експериментальну технології, а також метод самостійного навчання. Визначаючи якийсь 3 цих підходів домінуючим, викладач вибирає його у навчальній діяльності й активно використовує. Вибір певного напрямку як домінуючого спонукає викладача на пошуки таких видів діяльності та методів, які будуть найбільш широко застосовані на заняттях. Усі вищеназвані технологічні напрями щільно пов'язані між собою $[3,124]$. 


\section{ТЕНДЕНЦІЇ РОЗВИТКУ СУЧАСНОЇ МУЗИЧНО-ПЕДАГОГІЧНОЇ ОСВІТИ}

Інтерактивна технологія сприяє використанню діалогових методів навчання, у процесі яких студенти вчаться критично мислити, приймати виважені рішення, брати активну участь у дискусіях. Інтерактивне навчання сприяє розвитку творчої взаємодії викладача зі студентами, у процесі якої активність педагога не пригнічує творчої активності студентів. Використання різноманітних інтерактивних методів навчання (інтерв'ювання, дискусія, “мозкова атака", круглі столи, метод проектів тощо) слугує простором для ефективного розвитку комунікативності майбутніх викладачів мистецьких дисциплін. Основними функціями цієї стратегії доцільно виокремити наступні: комунікативну, інтерактивну та афективну.

Комунікативна функція полягає у встановленні контакту як стану обопільної готовності до прийому та передачі повідомлення, підтриманні взаємозв'язку в процесі музично-педагогічної взаємодії; активному обміні повідомленнями (інформацією, думками, рішеннями), наданні інформації за запитом або отриманні відповіді на запит від партнера; в усвідомленні та фіксації власного місця в системі рольових, ділових, міжособистісних зв'язків спілкування; у здійсненні сугестивного впливу на зміну стану, поведінки, особистісно-смислової та ціннісномотиваційної сфери студентів.

Інтерактивна функція педагогічного спілкування - це, перш за все обмін ідеями, діями та здатність відстоювати свої ідеї, остаточно доводити свою точку зору. Тут доречно нагадати, що між індивідами або соціальними групами можливі два основні типи взаємних стосунків: симетричні (рівноправні) та асиметричні (нерівноправні) і якщо симетричні відносини характеризуються взаємною допомогою, то в асиметричних закладені авторитарні тенденції. Якщо вчитель зацікавлений розвитком особистісної сфери учнів, то він буде прагнути до оволодіння школярами навичок соціальної поведінки, діалогової взаємодії тощо.

Загалом, виокремлюючи основні вимоги до майбутніх фахівців, доцільно зазначити, що вони повинні володіти: навичками міжособистісного спілкування, знати професійну етику та вміти застосовувати етичні принципи і норми поведінки у майбутній продуктивній діяльності, постійно прагнути до підвищення свого науково-методичного рівня, буги готовими до участі в дослідженнях, котрі сприяють удосконаленню практичної діяльності, тощо. 3 цією метою у зарубіжних країнах найбільш широко використовуюся технології експериментального та самостійного навчання.
Експериментальна технологія є ефективною в силу того, що вона зорієнтована на діяльність, що підвищує процес запам'ятовування матеріалу. Методи експериментальної технології (рольові ігри, драматизація, експеримент тощо) сприяють підвищенню якості засвоєння навчального матеріалу. За своєю природою експериментальна технологія індуктивна, сконцентрована на учнях й орієнтована на діяльність. Основне в ній не досягнення мети, а процес іiі досягнення. Ця технологія може використовуватися як у навчальній аудиторії, так і за їі межами. Вона підвищує запам'ятовування інформації. Студенти, як правило, більш мотивовані, коли вони беруть безпосередню участь у вивченні матеріалу. Усі залучені технології повинні бути щільно пов'язані між собою [3, 134].

Технологія самостійного навчання $\epsilon$ поширеною тому, що у кожному конкретному випадку педагог очікує від студента аналізу проблему, яка поставлена на заняттях, формування висновки і вживання заходів. До цієі стратегії належать методи, які стимулюють розвиток індивідуальної ініціативи учнів, а це саме: індивідуальні дослідницькі проекти, есе, навчання за допомогою комп'ютерних технологій, доповіді тощо. У процесі цієї роботи студент виконує певні завдання під безпосереднім керівництвом викладача.

При роботі зі студентами вважається за необхідне використання таких методів: аналітичні бесіди, порівняльні аналізи музичних творів та їх інтерпретацій, створення проблемних ситуацій, а також всі форми безпосереднього сприйняття музики, а саме: слухання і виконання творів, їх самостійну трактовку, самооцінку своєї діяльності, рецензії на аналогічну роботу своїх товаришів.

Притаманний сьогоденню всебічний науковий аналіз природних потреб та духовних прагнень людини, джерел і чинників розмаїття спонук, мотивацій, обумовленостей, усталених і водночас мінливих реалій багатовимірних суб'єктивних і об'єктивних світів індивіда та соціуму засвідчує нагальну потребу людства ступити на більш високий щабель самоусвідомлення, потребу в гуманізації власне життєсмислів. Покликане протистояти процесам дегуманізації суспільства, мистецтво, як засіб духовного розвитку людини і передачі досягнутого наступним поколінням, потребує не менш свідомого і відповідального перегляду свого місця в сьогоденних процесах. Соціокультурне явище масштабу свідомої духовної практики нації ще очікують комплексні дослідження, в яких глибоко і грунтовно буде вказане місце і перспективи цього феномену [4, 179]. 
Збережені упродовж тисячоліть глибинні архетипи колективної свідомості праукраїнців, як потужні культуротворчі чинники сьогоднішньої української ментальності, на часі постають також і органічним знаряддям консолідації національно свідомої української громади, і на наш погляд, безумовно заслуговують подальшого розвитку.

Перегляд і творче переосмислення значимості для духовного життя нації музичної культури, стану розвитку чинників іiї глибинного впливу в світлі сучасних філософських та педагогічних поглядів на роль та значення музичної культури у формуванні світогляду, національної самосвідомості, моральноестетичної культури особистості засвідчують потребу втілення цілого комплексу нових вимог до підготовки сучасного педагога-музиканта.

Складність професійної діяльності вчителя музики полягає в тому, що вона вимагає від вчителя знань, умінь та навичок у загально-педагогічній сфері, музично-педагогічній та виконавській.

У сучасних освітніх умовах система підготовки майбутніх учителів музичного мистецтва, як керівників дитячих хорових колективів, у ВНЗ спрямована на формування i розвиток професіоналів, здатних здійснювати художньотворчу діяльність. Але, у свою чергу, це вимагає від студентів опанування навичками самоосвіти, методами роботи з різними за віком хоровими колективами, індивідуальним підходом до навчання, розвитком музично-творчих якостей для продуктивної хормейстерської діяльності, оволодінням комплексом художньо-творчих умінь.

Ціннісний аспект професійної діяльності вчителя музичного мистецтва полягає не у тотожності своїх знань, своєї позиції щодо певної музично-освітньої концепції, а у розвитку цього знання, його перетворенні, введенні нового смислу, власної оригінальної інтерпретації. У ході художньо-педагогічної інтерпретації, коли учитель пропускає через себе цінності певної культури, в аспекті власного бачення, відбувається самореалізація його як особистості, професіонала, засвоєння ним інновацій, що з'являються в музично-освітній практиці, та обгрунтування власної позиції щодо них, тобто вирішується питання щодо можливості й доцільності їх використання в конкретних педагогічних умовах.

Активно оперуючи новітніми технологіями навчання, студент вдосконалює пошукову, творчу діяльність, піднімається на нову ступінь пізнання, активізує пізнавальну діяльність, самостійність, зацікавленість у своїй роботі.

Висновки. Творче використання позитивного зарубіжного досвіду та ефективне використання вітчизняних здобутків дозволяє уникнути застарілих підходів до професійної підготовки майбутніх викладачів мистецьких дисциплін та визначити оптимальні шляхи їі подальшого розвитку на основі вивчення сучасного стану цієї проблеми в Україні. Це дає змогу ефективніше застосовувати набутий досвід оцінювання знань студентів на всіх етапах їх навчання у вищій школі, що у свою чергу дозволить врахувати ці вимоги до професійної підготовки майбутніх педагогів-музикантів.

\section{ЛІТЕРАТУРА}

1. Жигаль 3. Педагогічні інновації в теорії та практиці загального музичного виховання/ 3.Жигаль // Молодь і ринок. - Дрогобич: Коло, 2006. - №8(23). - C. 112-114.

2. Зязюн І.А. Краса педагогічної дії: навч. посіб. для вчителів, аспірант., студ. /I. А. Зязюн, Г. М. Сагач. - К.: Українсько-фінський ін-т менеджменту $i$ бізнесу, 1997. - 302 c.

3. Козир А.В. Професійна майстерність учителів музики: теорія і практика формування в системі багаторівневої освіти: монографія /А.В. Козир. Київ: НПУ ім. М.Драгоманова, 2008. - 378 с.

4. Олексюк О.М. Ткач М.М. Педагогіка духовного потенціалу особистості: сфера музичного мистеитва: навч. посіб./ О.М. Олексюк, М.М. Ткач. -К.: Знання України, 2004. - 264 с.

5. Фуллан М. Сили змін: вимірювання глибини освітніх реформ. /М. Фуллан [перек. з англ. Г.Шиян, Р.Шиян]. - Львів: Літопис, 2000. - 269 с.

\section{REFERENCES}

1. Zhigal, Z. (2006). Pedagogichni innovacii v teorii ta praktici zagalnogo myzichnoogo vihovannja [Pedagogical innovations in the theory and practice of general musical education]. Youth and market. Drohobych: Kolo, no. 8 (23), pp. 112-114. [in Ukrainian].

2. Zyazun, I.A. (1997). Krasa pedagogichnoi diji [The beauty of pedagogical action]. Kyiv: UkrainianFinnish Institute of Management and Business Publ., 302 p. [in Ukrainian].

3. Kozyr, A.V. (2008). Profesiyna maysternist vchiteliv muziki: teoriya i praktika formyvannja $v$ sistemi bagatorivhevoi osvitu [Professional mastery of music teachers: theory and practice of formation in the system of multilevel education]. Kyiv: NPU them. M. Drahomanov Publ., 378 p. [in Ukrainian].

4. Olexyuk, O.M. \& Tkach, M.M. (2004). Pedagogika dyhovnogo potencialy osobistosti: sfera myzichnogo mistectva [Pedagogy of spiritual potential of the person: sphere of musical art].Textbook. Kyiv: Knowledge of Ukraine Publ., 264 p. [in Ukrainian].

5. Fullan,M. (2000). Sili zmin vimirjyvannja glibuhu osvitnih reform [The forces of change: measuring the depth of educational reform] trans. from english G. Shiyan, R. Shiyan. Lviv: Chronicle, 269 p. [in Ukrainian].

Стаття надійшла до редакції 02.02.2018 